\title{
Effect of telmisartan on blood glucose levels in euglycemic albino rats
}

\author{
Siddamma Amoghimath ${ }^{1}$, Mrutyunjay Mirje ${ }^{2, *}$ \\ ${ }^{\mathbf{1}}$ Assistant Professor, ${ }^{\mathbf{2}}$ Associate Professor, Dept. of Pharmacology, Gadag Institute of Medical Sciences, Gadag, Karnataka, India
}

*Corresponding Author:

Email: mirjemrutyunjay@gmail.com

\begin{abstract}
Introduction: Diabetes is considered primary risk factor for heart disease and comorbidities in older people and in children. Due to escalating epidemic, diabetes is concerned high profile public health problem.

Materials and Methods: Swiss albino rats weighing around 150-200gms of either sex were randomly selected from the central animal facility. Animals were randomly divided into 2 groups, six animals in each group. A group of 3 rats were kept in individual cages. The control was given $0.5 \mathrm{ml} 1 \%$ Gum acacia, test group was given Telmisartan at the dose of $7.2 \mathrm{mg} / \mathrm{kg} / \mathrm{day}$. All the drugs were given orally and for the period of 5 days. All rats were fasted overnight before the 5 th day. On the $5^{\text {th }}$ day glucose $(0.6 \mathrm{gm} / \mathrm{kg}$ body weight) was given orally using oral feeding tube and oral glucose tolerance test (OGTT) was performed. Blood was collected by tail snipping method and capillary blood glucose was assessed at 0,60 , and 150 minutes using a glucometer.

Results: Fall in capillary blood glucose level was seen in Telmisartan group at all-time intervals when compared to control group. Conclusion: Telmisartan when given orally for 5 days showed fall in blood glucose level in swiss albino rats.
\end{abstract}

Keywords: Adipokines, Capillary blood glucose, Diabetes, Euglycemic.

\section{Introduction}

There are two broad categories of Diabetes. They are type $1 \mathrm{DM}$ and type $2 \mathrm{DM}$. Type $1 \mathrm{DM}$ is due to complete or near-total insulin deficiency. Type $2 \mathrm{DM}$ is heterogeneous group of disorders characterized by variable degrees of insulin resistance or impaired insulin secretion. Impaired insulin secretion is due to abnormality in glucose transporters (GLUT2) on $\beta$ cells or they do not respond to high concentration of glucose in blood. Peripheral insulin resistance is because of down regulation of insulin receptors due to obesity and genetic factors. The metabolic dysregulation and complications are associated with diabetes are due to glucotoxicity, lipotoxicity, formation of Advanced Glycation End Products (AGEs), Protein kinase $\mathrm{C}$ and Hexosamine pathway products. ${ }^{1}$ All these lead to morbidity and mortality in patients as a result of microvascular and macrovascular complications. ${ }^{2}$

When renin binds to Pro Renin Receptor (PRR) the catalytic activity of renin is augmented. However, pro renin or renin can dissociate from PRR to return to their original state. Non enzymatic activation of pro renin plays a major role in local Renin Angiotensin system (RAS), where pro renin exerts effects via Angiotensin II dependent and also through independent pathways. Angiotensin II acts on $\mathrm{AT}_{1}$ receptors on tissue cells to produce effects on cell growth, inflammation, and apoptosis. $^{3}$

Adipocytes secrete a number of biological products (adiponectin, non-esterified free fatty acids, retinol binding protein 4, leptin, TNF- $\alpha$ and resistin). Particularly central obesity causes inflammation (LTB4 an inflammatory molecule) which can lead to type 2 diabetes by releasing inflammatory cytokines. Extra fat in the liver and mesentery activates the resistant macrophages and immune cells. These macrophages activate and release LTB4 and other immune signaling molecules to a positive feedback loop by release of more LTB4. Inflammation is chronic state in obesity and LTB4 starts activating other cells also. Macrophages of liver, fat and skeletal muscle cells have LTB4 receptors on their surfaces and gets activated when LTB4 binds to them. In obesity these cells become inflamed and release adipokines leading to insulin resistance. ${ }^{4}$

Molecular mechanism underlying the insulin sensitizing action of adiponectin, indicates that stimulation of glucose utilization and fatty acid combustion by adiponectin ,through activating AMPK(5' Adenosine Monophosphate kinase) and there by directly regulating glucose metabolism and insulin sensitivity. ${ }^{5,6}$

Angiotensin receptors blockers reduce inflammation, regulate cell growth, apoptosis, decreasing fibrosis, decreasing collagen deposition of $\beta$ cell, skeletal muscle cell and adipose tissue. These are expressed because it increases adiponectin directly by inhibiting the activation of $\mathrm{AT}_{1}$ receptors by angiotensin II and also mediated by PPAR- $\gamma$ and AMP (5' Adenosine Monophosphate) activated protein kinases. Telmisartan is a partial PPAR $\alpha$ agonist and induces PPAR $\alpha$ expression.

Hypothesis:_Telmisartan is expected to decrease the blood sugar level through its activity of blocking action of angiotensin II on $\mathrm{AT}_{1}$ receptor and promoting the activity of adiponectin and decreasing the activity of adipokines. 


\section{Materials and Methods}

After getting the permission from Institutional Animal Ethics Committee.

Animals were randomly divided into 2 groups, six animals in each group. A group of 3 rats were kept in individual cages and animals were identified by a mark on the tail with a permanent marker and the cages were identified with label pasted on the cages with name of the group written on them.

On the day of experiment the rats were divided into 2 groups containing 6 animals $(n=6)$ in each group [control and test group-T1].The test group T1: Telmisartan, and Control group was administered orally for 5 days.

The groups that were involved in OGTT were

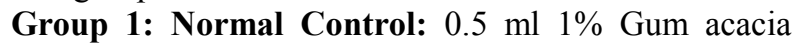
(oral)

Group 2: Test 1: Telmisartan $7.2 \mathrm{mg} / \mathrm{kg}$ body weight (oral).

All rats were fasted overnight before the 5th day. On the $5^{\text {th }}$ day OGTT was performed 1 hour after the last dose.Glucose at the dose of $0.6 \mathrm{gm} / \mathrm{kg}$ body weight was given orally using oral feeding tube. Following this, the animal was placed in a suitable restrainer, the tip of the tail was cleaned with a disinfectant and was punctured under aseptic precautions. Blood was collected by rat tail vein puncture method. The Capillary blood glucose was assessed at 0,60 , and 150 minutes of time intervals using a glucometer (ACCUCHECK). Blood drop was used for capillary blood glucose estimation (CBG).

\section{Statistical analysis}

Statistics was done by measuring range, mean and standard deviation. These tests were done to rule out sampling variation. The test of significance was done using two way repeated measures, Analysis of Variance (ANOVA) at appropriate places. Following ANOVA, Tukey's Post Hoc Test was done to compare mean of one group with mean of another group. $\mathrm{P}<0.05$ is considered statistically significant

All the statistical analysis was done by using IBM SPSS 21 software.

\section{Results}

At all-time intervals the fall in blood glucose levels in Telmisartan group was more when compared to control and was statistically significant $(\mathrm{p}<0.05)$.

Table 1: Capillary Blood glucose (CBG) levels in different groups

\begin{tabular}{|l|c|c|c|}
\hline $\begin{array}{c}\text { Time interval } \\
\text { during OGTT }\end{array}$ & $\begin{array}{c}\text { Control group } \\
\mathbf{N}=\mathbf{6}\end{array}$ & $\begin{array}{c}\text { Telmisartan group } \\
\mathbf{N = 6}\end{array}$ & $\begin{array}{c}\text { Fall in CBG levels Telmisartan } \\
\text { group compared to control group }\end{array}$ \\
\hline $0 \mathrm{~min}$ & $72.66 \pm 4.54$ & $67.16 \pm 3.76$ & $5.5 \pm 0.78^{*}$ \\
\hline $60 \mathrm{~min}$ & $100.16 \pm 3.86$ & $87.83 \pm 4.07$ & $12.33 \pm 0.21^{*}$ \\
\hline $150 \mathrm{~min}$ & $82.16 \pm 4.53$ & $73.33 \pm 4.27$ & $8.83 \pm 0.26^{*}$ \\
\hline
\end{tabular}

Data is expressed as mean $\pm \mathrm{SD},{ }^{*} \mathrm{p}<0.05$ and $^{* *} \mathrm{p}<0.01$ compared with control

\section{Graph 1: Blood glucose levels in control and Telmisartan group}

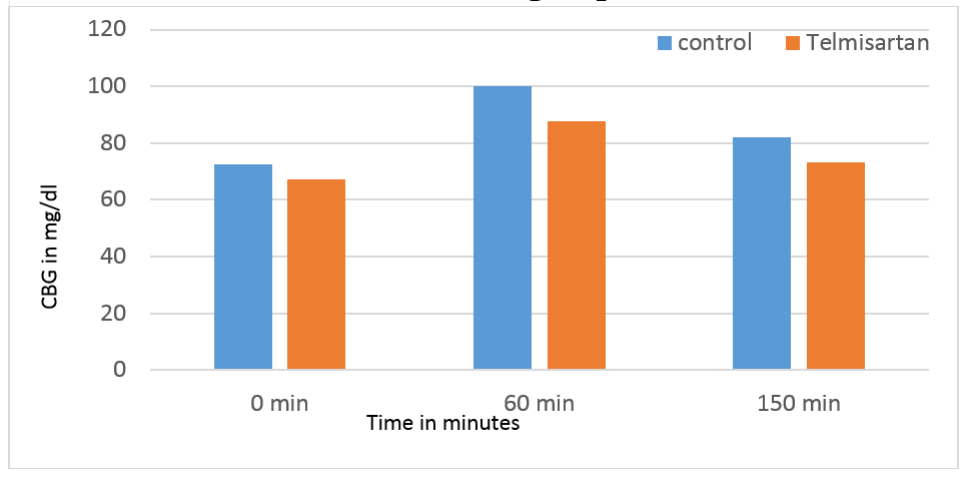

Table 2: Fall in Blood glucose level in Telmisartan group

Data is expressed in percentage

\begin{tabular}{|l|c|c|c|}
\hline Sl no & $0 \mathrm{~min}$ & $60 \mathrm{~min}$ & $150 \mathrm{~min}$ \\
\hline Telmisartan & 7.56 & 12.3 & 10.74 \\
\hline
\end{tabular}


Table 3: Change in blood glucose levels at different time intervals

\begin{tabular}{|c|c|c|c|}
\hline Sl no & \multirow{2}{*}{$\begin{array}{c}\text { Time } \\
\text { interval }\end{array}$} & \multicolumn{2}{|c|}{ Change in CBG values mg/dl } \\
\cline { 3 - 4 } & $0-60 \mathrm{~min}$ & -27.5 & $-20.67^{*}$ \\
\hline 1 & Control & Telmisartan \\
\hline 2 & $60-150 \mathrm{~min}$ & 18 & $14.5^{*}$ \\
\hline 3 & $0-150 \mathrm{~min}$ & -9.5 & $-6.17^{*}$ \\
\hline
\end{tabular}

Data is expressed as $\mathrm{mg} / \mathrm{dl}$, ${ }^{*} \mathrm{p}<0.05$ compared with control

Graph 2: Difference in blood glucose levels at different time intervals

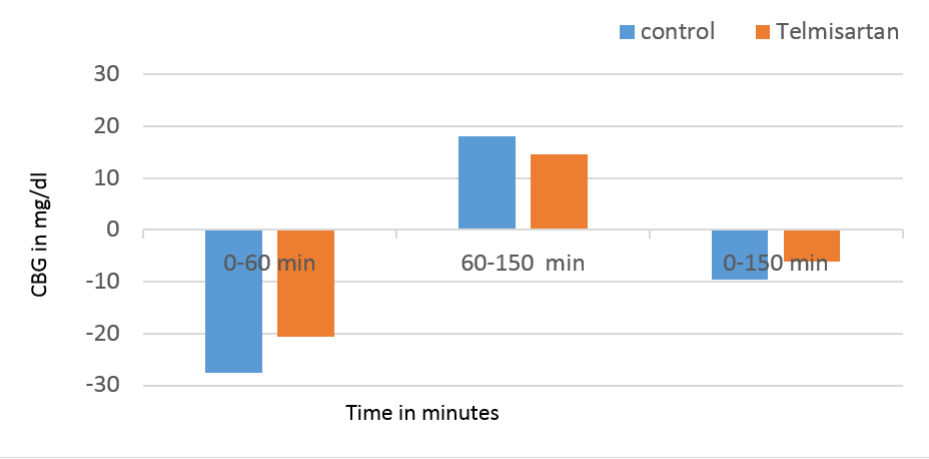

Table 4: Difference in blood glucose levels between control group and Telmisartan group at various time intervals

\begin{tabular}{|c|l|c|}
\hline S no & $\begin{array}{c}\text { OGTT time interval of } \\
\text { Control - OGTT time } \\
\text { interval of Test group }\end{array}$ & $\begin{array}{c}\text { Difference in CBG values } \\
\text { of control and Telmisartan } \\
(\mathbf{C}-\mathbf{T})(\mathbf{m g} / \mathbf{d l})\end{array}$ \\
\hline 1 & $0-0 \mathrm{~min}$ & $5.5^{*}$ \\
\hline 2 & $0-60 \mathrm{~min}$ & $-15.17^{*}$ \\
\hline 3 & $0-150 \mathrm{~min}$ & $-0.67^{*}$ \\
\hline 4 & $60-0 \mathrm{~min}$ & $33^{*}$ \\
\hline 5 & $60-60 \mathrm{~min}$ & $12.33^{*}$ \\
\hline 6 & $60-150 \mathrm{~min}$ & $26.83^{*}$ \\
\hline 7 & $150-0 \mathrm{~min}$ & $15^{*}$ \\
\hline 8 & $150-60 \mathrm{~min}$ & $-5.67^{*}$ \\
\hline 9 & $150-150 \mathrm{~min}$ & $8.83^{*}$ \\
\hline
\end{tabular}

${ }^{*} \mathrm{p}<0.05$ compared with control

Graph 3: Difference in blood glucose levels between control and Telmisartan group

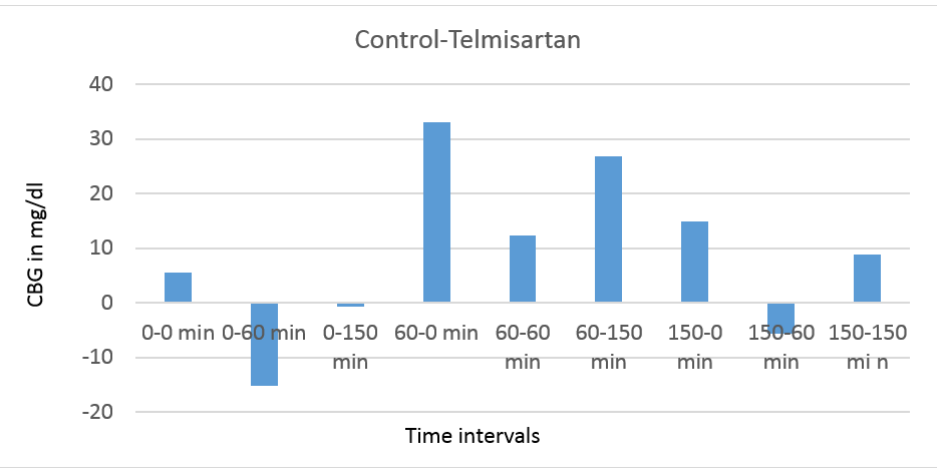

Discussion

Angiotensin II exerts several cytokine like actions via the AT1 receptor and can stimulate multiple signalling pathways, activate several growth factor receptors, promote the formation of reactive oxygen species (ROS) and other proinflammatory responses. Angiotensin II can also cause insulin resistance by 
interfering with the insulin-stimulated increase in insulin receptor substrate 1-associated PI3K activity. ${ }^{7,8}$

Long-term inhibition of the renin-angiotensin system ameliorates endothelial dysfunction associated with aging through the inhibition of the synthesis of COX-2-derived vasoconstricting factors and superoxide anions. Angiotensin II also stimulates the production of superoxide radicals, TGF- $\beta$, endothelin, and plasminogen activator inhibitor (PAI-1), which ultimately interferes in $\mathrm{NO}$ action. ${ }^{9,10}$

Adipose tissue secretes a variety of hormones (known collectively as adipokines) that can modulate endothelial function. For example, TNF- $\alpha$ is a proinflammatory cytokine secreted by adipose cells that may cause insulin resistance and endothelial dysfunction. ${ }^{11}$

The action of adiponectin is to decrease in hepatic gluconeogenesis and increase the muscle glucose transport. The ATP production is increased as a result of increased energy consumption and fatty acid oxidation in the peripheral tissues. Adiponectin has an important role in insulin secretion. There are various studies from clinical, experimental and genetic scenario which support the association between insulin secretion/insulin resistance and adiponectin. ${ }^{12-14}$

The induction of adiponectin in fact might be caused by secondary effects involving other PPAR- inducible genes and not by specific activation of the PPAR response elements. Angiotensin receptor blockers have a partial agonist action of PPAR $\gamma$ and are expected to have beneficial effects on insulin resistance by increasing adiponectin levels. ${ }^{15-17}$ Oral glucose tolerance test is a method in which the effect of glucose on insulin secretion is studied by measuring the peripheral blood glucose at various time intervals.

In the present study Table 1 and Table 2, in the control group the mean blood glucose level was 72.66 $\mathrm{mg} / \mathrm{dl}$ at $0 \mathrm{~min}$ which increased to $100.1 \mathrm{mg} / \mathrm{dl}(37.76 \%)$ at $60 \mathrm{~min}$ and to $82.16 \mathrm{mg} / \mathrm{dl}(13.07 \%)$ at $150 \mathrm{~min}$ with a difference of $9.5 \mathrm{mg} / \mathrm{dl}$ (decrease) between $0-150 \mathrm{~min}$. The Telmisartan showed fall in CBG levels when compared to control at all-time intervals, $0 \mathrm{~min}$ $67.16 \mathrm{mg} / \mathrm{dl}, 60 \mathrm{~min} 87.83 \mathrm{mg} / \mathrm{dl}$ and $150 \mathrm{~min} 73.33 \mathrm{mg} / \mathrm{dl}$, with maximum fall at $60 \mathrm{~min}$. The difference in the fall of blood glucose level compared to control at $0 \mathrm{~min}$ was $5.5 \mathrm{mg} / \mathrm{dl}, 60 \mathrm{~min}$ was 12.33 and $150 \mathrm{~min}$ was $8.83 \mathrm{mg} / \mathrm{dl}$. When compared to control the inter interval difference in the blood glucose levels was $20.67 \mathrm{mg} / \mathrm{dl}$ at $0-60 \mathrm{~min}$, $14.5 \mathrm{mg} / \mathrm{dl}$ at $60-150 \mathrm{~min}$ and $6.17 \mathrm{mg} / \mathrm{dl}$ at $0-150 \mathrm{~min}$.( Table 3)

When compared to control the fall in the blood glucose level in Telmisartan group at 0 min was 5.5 $\mathrm{mg} / \mathrm{dl}, 60 \mathrm{~min}$ was $12.33 \mathrm{mg} / \mathrm{dl}$ and at $150 \mathrm{~min}$ was $8.33 \mathrm{mg} / \mathrm{dl}$. The maximum percentage fall in the blood glucose level was at $60 \mathrm{~min}$ indicating the peak action of Telmisartan at this time. The inter interval action of Telmisartan was more at 60-150 min when compared to control.
The difference in the blood glucose level between control and Telmisartan is more at 0-60 $\mathrm{min}$ ($15.17 \mathrm{mg} / \mathrm{dl}), 60-60 \mathrm{~min}(12.33 \mathrm{mg} / \mathrm{dl})$ and $150-60 \mathrm{~min}(-$ $5.67 \mathrm{mg} / \mathrm{dl})$. (Table 4)

Thus to conclude Telmisartan after 5 day continuous administration reduces the blood glucose levels in the euglycemic rats. Probably indicating the action of Telmisartan (ARB) to promote basal insulin secretion minimally and also moderate glucose induced insulin secretion.

The test drug Telmisartan is most frequently prescribed ARB's for hypertension alone or associated with diabetes. It is known to cause less side effects and proved to be safe even on long term administration hence can be used safely. The activity and behaviour of test group of rats were normal all throughout the study.

\section{Conclusion}

The test drug Telmisartan in the dose of $7.2 \mathrm{mg} / \mathrm{kg}$ body weight have shown hypoglycemic activity in euglycemic albino rats in OGTT model. The test drug is likely to be better acting drug with consistent and sustained hypoglycemic effect which requires further evaluation. before the compound could be used as an adjuvant to standard hypoglycemic agents for better glycemic control or as monotherapy in mild to moderate cases.

Thus, to conclude Telmisartan causes decrease in the blood sugar level through its activity of blocking action of angiotensin II on $\mathrm{AT}_{1}$ receptor and promoting the activity of adiponectin and decreasing the activity of adipokines.

\section{Limitations of this study}

1. The study has been carried out only in one species of animals viz — rats and requires further studies in 2 rodent animal models and later in human subjects.

2. Only the fasting blood glucose were evaluated in this study without correlation with other parameters like PPBS, serum insulin, $\mathrm{Hb}_{\mathrm{Alc}}$ etc.

\section{Acknowledgements: Nil \\ Conflict of Interest: Nil}

\section{References}

1. Siddamma Amoghimath, Suresha R N, Jayanthi M K, Shruthi S L. To evaluate the effect of olmesartan on blood glucose levels and blood lipid levels in streptozotocin induced diabetic rats. Indian J Physiol Pharmacol 2018; 62(1):105-112.

2. Alvin C Powers. Harrison's principles of internal medicine. In: Longo, Fauci, Kasper, Hauser, Jameson, Loscalzo. Diabetes mellitus. Mc Graw Hill, New York 2012:2152-2180.

3. Bertram G Katzung. Basic and clinical pharmacology. In: Neal L Benowitz. Mcgraw hill, New Delhi 2012:185-87.

4. Nicholson G and Hall G.M. Diabetes mellitus: new drugs for a new epidemic. British Journal of Anaesthesia 2011; 107(1): 65-73.

5. Kohlstedt K, Gershome C, Trouvain C, Hofmann W K, 
Fichtlsherer S, Fleming I. Angiotensin converting enzyme inhibitor modulate cellular retinol binding protein and adiponectin expression in adipocytes via the ACE dependent signalling casade. Molecular Pharmacology 2009;75:685-692.

6. Chandran M, Phillips S A, Ciaraldi, Henry R R.

Adiponectin more than just another fat cell harmone. Diabetes care 2008;26(8):2442-2450.

7. Hunyady L, Catt KJ. Pleotrophic AT1 receptor signaling pathways mediating physiological and pathogenic actions of angiotensin II. Mol Endocrinol. 2006;20(5):953-70.

8. Popa C, Netea MG, Van Riel PL, Van der Meer JW, Stalenhoef AF. The role of TNF $\alpha$ in chronic inflammatory condition intermediary metabolism and cardiovascular risk. Journal of Lipid Research 2007;48(4):751-762.

9. Bikash Medhi, Ajay Prakash. Introduction to experimental pharmacology. In: Bikash Medhi, editors. Practical manual of experimental and clinical pharmacology. New Delhi: Jaypee; 2010.p. 23-25.

10. Mukai Y, Shimokawa H, Higashi M, et al. Inhibition of renin- angiotensin system ameliorates endothelial dysfunction associated with aging rats. Arterioscler Thromb Vasc Biol. 2002;22:1445-50.

11. Velloso L A, Folli F, Sun X J, White M F, Saad M J and Kahn C R. Crosstalk between insulin and angiotensin II signalling systems. Proc Natl Acad Sci U S A 1996;93(22):12490-12495.

12. Rodriquez A, Fortuño A, Gómez-Ambrosi J, Zalba G, Diez J, Frühbeck G. The inhibitory effect of leptin on angiotensin II-induced vasoconstriction in vascular smoth muscle cells is mediated via a nitric oxide-dependent mechanism. Endocrinology 2007;148(1):324-31.

13. Rydén M, Arner P. Tumour necrosis factor-alpha in human adipose tissue - from signaling mechanisms to clinical implications. J Intern Med 2007;262:431-8.

14. Xita $\mathrm{N}$ and Tsatsoulis A. Adiponectin in Diabetes Mellitus. Current Medicinal Chemistry 2012;19(32):5451-8.

15. Barth N, Langmann T, Scholmerich J, Schmitz G, Schaffler A: Identification of regulatory elements in the human adipose most abundant gene transcript-1 (apM-1) promoter: role of SP1/Sp3 and TNF-alpha as regulatory pathways. Diabetologia 2002;45(10):1425-33.

16. Schupp M, Janke J, Clasen R, Unger T, Kintscher U. Angiotensin type 1 receptor blockers induce peroxisome proliferator-activated receptor gamma activity. Circulation 2004;109(17):2054-57.

17. Juris J Meier, Bjoern A Menge, Thomas G K Breuer, Christophe A Mu“ller, Andrea Tannapfel, Waldemar Uhl. Functional Assessment of Pancreatic Cell Area in Humans. DIABETES 2009;58:1595-1603. 